\title{
Urban Ethnobotany in Argentina: Theoretical advances and methodological strategies
}

Julio Alberto Hurrell ${ }^{\prime}$

\begin{abstract}
Urban Ethnobotany is a discipline of relatively recent development, allowing new questions and interesting challenges from both theoretical and methodological point of view. This has become evident from the development of a research line in the metropolitan area Buenos Aires-La Plata, the largest in extension and population of Argentina. This research was carried out in the Laboratorio de Etnobotánica y Botánica Aplicada (LEBA), Facultad de Ciencias Naturales y Museo, Universidad Nacional de La Plata, Argentina. In this frame, the ongoing investigations constitute an example of feedback between theory and practice in ethnobotanical studies. How the botanical knowledge is composed in urban pluricultural contexts? Is it possible to find traditional botanical knowledge in these contexts? How is the local botanical knowledge transmitted? How is its dynamic? Assuming the premise that knowledge guides the actions, then how botanical knowledge guides the selection and utilization strategies of plants and its products in urban areas? The aim of this contribution is try to answer these, and other relevant questions. Some basic principles about Ecology, Biocultural Ecology, and Ethnobotany as different levels of approximation within a unified field were discussed. Later, advances in the theoretical field of urban ethnobotany were considered, as reflection product on complexity of the obtained results. These advances were translated into methodological strategies based on different criteria to evaluate the urban botanical knowledge underlying the circulation of plant products (exclusivity and visibility of these products, re-signification of its uses in contexts of change). Finally, a reflexive discussion on complexity of theoretical and methodological contexts allows us to rethink the developments in Urban Ethnobotany, and Ethnobotany in general.
\end{abstract}

Keywords: Ethnobotany, Biocultural Ecology, Ecology, Man-Plant environment

\section{INTRODUCTION}

Urban ethnobotany is a discipline of relatively recent development in Argentina wherein there have been diverse contributions (Cuassolo et al. 2010; Hilgert et al. 2010; Ladio et al. 2013; Pirondo et al. 2011; Richeri et al. 2010; Rovere et al. 2013, among others). This time, the contents focus on a pioneer research line on Urban Ethnobotany carried out in the Laboratorio de Etnobotánica y
Botánica Aplicada (LEBA), Facultad de Ciencias Naturales y Museo, Universidad Nacional de La Plata, Argentina. These researches are realized in the metropolitan area Buenos Aires-La Plata, the largest in extension and population of Argentina, and many of the results obtained in this conurbation are valid for other urban areas on the country.

In addition to data about diverse plants and their uses, results of this research line have

1 Laboratorio de Etnobotánica y Botánica Aplicada (LEBA), Facultad de Ciencias Naturales y Museo, Universidad Nacional de La Plata. Calle 64 no. 3, 1900-La Plata Universidad Nacional de La Plata. Consejo Nacional de Investigaciones Científicas y Técnicas (CONICET), Argentina. E-mail address: juliohurrell@gmail.com 
open the possibility to formulate new questions and propose interesting challenges from both theoretical and methodological standpoint. In this framework, the ongoing investigations constitute an example of feedback between theory and practice in ethnobotanical studies.

How the botanical knowledge is composed in urban pluricultural contexts? Is it possible to find traditional botanical knowledge in these contexts? How is the local botanical knowledge transmitted? How is its dynamic? Assuming the premise that knowledge guides the actions, then how botanical knowledge guides the selection and utilization of plants and its products in urban areas? The aim of this contribution is try to answer these, and other relevant questions.

\section{DISCIPLINARY FRAME}

\section{Ecology}

The theoretical basis guiding methodological strategies involves considering the Ethnobotany sensu lato as an ecological discipline (Hurrell and Albuquerque 2012). Notbecause Ethnobotany must be regarded as a sub-discipline of Ecology, but because it is sustained on the basic principles of Ecology as a context where ethnobotanical studies acquire meaning. This is possible if we consider the Ecology in the broadest sense: the study of relationships between organisms and their environment. In this definition, the concept of 'environment' includes not only the physical space but also other organisms of the same and other species. These elements interact in various ways within the system that compose, both in its current situation as in its evolution (Flos 2005; Margalef 1986, 1990, 1991). This integrative idea of Ecology clearly differs from other positions that tend to atomize and/or trivialize this science (Guerra Sierra and del Hierro 2008).

If we accept that Ecology is the science of the complex relationships between organisms and their environment, we must also accept the following premises:

1. The organism lives in its environment, do not live in an environment.
The organism specifies its environment through their behavior and their interactions with other living beings and the physical parameters. Life not only depends on the conditions of space, also modifies and configures those conditions. This concept of environment is closer to that of Umwelt or 'surrounding world' of the German early Ecology, different from the classical concept of physical environment: life (Leben) and its surrounding world (Umwelt) define one another and constitute a unity (totality). In this senses, the surrounding world is fundamentally independent of a given place (Thiemermann 1956) ${ }^{2}$.

\section{The organism which destroys its environment} destroys itself (Gregory Bateson).

The organism and its environment are not separate units but coupled systems that conforms a larger system ('organism-environment'). This idea enhances the previous approach: the organism lives in its environment. If a component of this larger system destroys the other, the whole system is denatured (Bateson 1972). When an organism dies, its environment dies with it. For the 'organism-environment' system, the structural coupling between its parts is its existence condition, therefore, is the variable that should be preserved (Maturana and Varela 1972).

\section{The organism-environment system changes} over time.

The organism-environment system is dynamic, it evolves. So, it constitutes both ecological and evolutionary unit. As a consequence of the previous item, the complex web of relationships between the organism and its environment is the 'unit of survival' (Bateson 1972). In Ecology, evolution goes beyond the scope of the species or populations level (the neo-Darwinian evolution). According to Jordi Flos, 'Definitely, the adaptability of a single

2 Throughout this contribution, various quotes corresponds to original editions. This 'old literature' does not imply that there are not various later editions and numerous papers that discuss and reformulate the original opinions of the authors. However, we preferred the original quote, first, because it contains the original idea in its 'purest form', and secondly, because it makes clear that in Ecology, Biocultural Ecology, and Ethnobotany many 'old ideas' have been ignored or neglected. 
species goes through its success in collaborate with the construction and maintenance of a system, in which the internal flow of information is maximized' (Flos 2005). ${ }^{3}$

\section{Biocultural ecology}

If the organisms that compose the 'organismenvironment' system to which we refer are human beings, then the disciplinary context corresponds to the Biocultural Ecology. This is defined as the study of relationships between humans and their environment (Albuquerque and Hurrell 2010; Hurrell 1987). This context implies a deeper analysis level, but always within the broader framework of Ecology. Therefore, assumptions relating to that broadest context should also apply to the Biocultural Ecology.

A central concept in Biocultural Ecology is the biocultural diversity, defined as the diversity of life both in its biological dimension (species, communities, and ecosystems) as in its cultural dimension (knowledge, beliefs, practices, language). These dimensions are not separate nor pass on parallel pathways; on the contrary, they interact in complex ways and co-evolve, both globally and locally (Maffi 2001, 2005, 2007). Note that the concept of co-evolution is resonant with the idea about the organism-environment system evolution (indeed, the organism and its environment 'do not intersect at infinity', they go together). The integral vision of 'human environment', natural and cultural at the same time, it means overcoming to the old dichotomy between nature and culture. If we accept the integration, we must also accept the following premises:

1. The man is a cultural being by nature, because it is a natural being by culture (Edgar Morin).

3 The information concept as indicator of the complexity of a system was introduced in Ecology by Ramon Margalef, based on the integration of communication theory, cybernetics, and thermodynamics of open systems far from equilibrium (Flos 1984, 2005; Margalef 1980, 1990, 1991; Prigogine 1972). For a more detailed discussion, see Morin (1980).
For humans, the positions that tend to dissociate nature and culture, as well as those that tend to integrate them, are cultural products. 'Man is a natural being by culture' because we speak about nature from our own culture. 'Man is a cultural being by nature' because culture is our human nature (Morin 1983, 1990). As ideas guide our actions, we can start from a dissociating concept or an integrating notion regarding nature and culture, and our explanatory models will be consistent with that initial conception.

2. Since Darwin we admit that we are sons of primates, but not that we ourselves are primates (Edgar Morin).

The 'nature-culture' integrative conception is expressed when considering the man-environment system complexity. However, this complexity often is found in a declarative level (in the sense of declaring or explain in a clear way something that is not). Many statements about overcoming the 'nature vs. culture' antinomy are not rooted in such overcoming (Morin 1983). In this sense, complex phenomena require complex explanations; otherwise, the explanatory models become reductionist (Morin 1982, 1985, 1990).

3. We're not outside the ecology for which we plan, we are always and inevitably a part of it (Gregory Bateson).

The field of Biocultural Ecology supposes the broader context of Ecology: if we destroy our environment, we destroy ourselves. What conceptions on nature and culture guide the strategies of environmental planners and conservation patterns? (Bateson 1972). The idea that we can appropriate nature (as a set of resources) is based on the nature-culture dissociation: we 'appropriated' something when that something is stranger to us. To this position (that we could call 'against nature') opposes another one more romantic: 'humanity must return to nature' ('against culture' position). We can ask ourselves: When we have gone of nature? Clearly, this also denotes the dissociation between nature and culture. 
In these matters it is important to reflect on which is our reference theoretical framework, that is, our starting point. If we start from distinct bases, even using the same procedures, we will get different conclusions.

\section{Ethnobotany}

Ethnobotany is situated into a deeper analysis level, within the broader framework of Biocultural Ecology, and this one in the most widespread of Ecology (Figure 1). Ethnobotany sensu lato is the study of the complex relationships between human beings and their plant environment (Albuquerque and Hurrell 2010; Hurrell 1987; Hurrell and Albuquerque 2012). Plant environment includes both plants, parts thereof, and products derived, as well as plant associations (both physiognomic and floristic). Thereby, among other areas, Ethnobotany deals with the present and past local knowledge about plants (Pochettino and Lema 2008), homegardens and horticultural activity (Pochettino et al. 2012a), the sites where plants and their products are marketed, its circulation and diffusion (Hurrell and Pochettino 2014; Pochettino et al. 2012b), physiognomies and communities, plant invasions and environmental change (Hurrell and Delucchi 2013).

\begin{tabular}{|lll|}
\hline Ecology & Organism & Environment \\
\hline $\begin{array}{l}\text { Biocultural } \\
\text { Ecology }\end{array}$ & $\begin{array}{l}\text { Human } \\
\text { beings }\end{array}$ & $\begin{array}{l}\text { Environment } \\
\text { (biocultural) }\end{array}$ \\
\hline Ethnobotany & $\begin{array}{l}\text { Human } \\
\text { beings }\end{array}$ & $\begin{array}{c}\text { Plant } \\
\text { Environment }\end{array}$ \\
\hline
\end{tabular}

Figure 1. Inclusive fields of Ecology, Biocultural Ecology and Ethnobotany.

One of the current challenges in Ethnobotany is to accept complexity, for which, a starting point is to assume the basic premises of Ecology (the organism is not separate from their environment) and Biocultural Ecology (nature and culture are not divorced). In this context, some considerations can be added:

\section{Lack of information can generate information} (Gregory Bateson)

Humans are not divorced from our plant environment. This becomes evident if we review the 'plant resources' concept, because we are who define what is a plant resource or what is not in each particular cultural context. Cultural relativity of the 'plant resources' concept is clearly evident: in many areas some plants are used (they are resources), while other are not used (they are not resources) although they are considered resources in other areas. Early, Alfred Kroeber (1920), criticized the ethnobotanists of his time because only considered the useful plants of their area of study, but not the plants not used there, but were utilized in other areas. This warning (usually neglected) is a valuable methodological tool that helps to define the local botanical knowledge, because it involves evaluating the information (knowledge that guides effective use), the absence of information (disregard), and the loss of information due to disuse (Hurrell et al. 2011) . $^{4}$

2. Knowledge guides the actions that allow reformulate it.

The study about botanical knowledge occupies much of the ethnobotanical literature. This is a system composed of diverse wisdoms and beliefs about the plant environment, guiding different patterns of behavior and strategies of selective action on the procurement, production and consumption of plants, plants thereof and their derivatives products (Pochettino and Lema 2008; Pochettino et al. 2012b). No knowledge is accessible directly, but it is possible to access to verbalized knowledge in an oral or written discourse (the discourse of informants interviewed). Knowledge guides diverse actions (discourses, practices), and through evaluating these actions is possible to reformulate the knowledge that generated them ${ }^{5}$.

4 In the communication theory, the absence of a message can be a message: 'The letter that you do not write, apologies you do not offer (...)can be sufficient and effective messages, because zero, in context, can be meaningful' (Bateson 1979).

5 This idea is related to the expression: 'the map is different to the territory' (Bateson 1979): knowledge (the territory), is inaccessible to us, we only have the map, that is, discourses, behaviors and actions that orients. 
3. Selective actions are adaptive, that is, they have evolutionary value.

The botanical knowledge is not static: it changes according to the adjustments of the human group to changing circumstances of their biocultural environment, within the frame of man-environment system (the ecological and evolutionary unit). This system is the context where changes have meaning. Domestication, varieties selection, plants identified as weed to be eradicated or tolerated, and the horticultural practices as a whole are an example of adaptive actions (Pochettino et al. 2012a). Weeds concept (plants growing in places where you do not want that they grow, Rapoport et al. 2009), is relative to the cultural context, as the resource concept.

\section{URBAN ETHNOBOTANY}

Several studies about the botanical knowledge have emphasized the study of called traditional botanical knowledge. This is considered characteristic of culturally homogeneous contexts, with a long experience of human group in its environment; knowledge is transmitted from generation to generation orally and in the shared practices, and the link between production and consumption is direct: those who consume produce. In contrast, the non-traditional botanical knowledge is assumed to be characteristic of culturally heterogeneous (pluricultural) contexts, with human groups without a large experience in the environment; knowledge is transmitted through the social means of communication, and the link productionconsumption is indirect: those who consume do not produce (Hurrell and Pochettino 2014).

This opposition of features may have comparative value, but it is necessary to clarify that both traditional and non-traditional botanical knowledge are relative terms, not mutually exclusive. Culturally homogeneous contexts in which the traditional botanical knowledge is located are not isolated from other cultural contexts, that is, they are not so 'homogeneous'. There are often fluid exchange of traditional knowledge and other non-traditional (including scientific knowledge). On the other hand, the non-traditional botanical knowledge is usually associated with urban areas. However, the urban botanical knowledge is not confined to that one.

In the course of our studies in the metropolitan area Buenos Aires-La Plata (Argentina), it has been evident that:

1. The urban botanical knowledge is a complex system according to the urban pluricultural context that includes non-traditional knowledge and knowledge linked to traditions (but not traditional sensu stricto). This kind of knowledge is related, for example with 'family traditions' or the traditions of groups of immigrants of different origin and time of residency in the area. The role of immigrants is crucial because they establish traditional markets, offering innovative plant products for the rest of the urban population. In this sense, these markets contribute greatly to increasing local plant biodiversity and constitute diffusion sources both knowledge and products. (Arenas et al. 2011, Hurrell et al. 2011; Pochettino et al. 2012b).

2. In the urban scenario, the urban botanical knowledge guides actions that are expressed in the circulation of plants and their products. These actions include selection strategies, assignment/ reassignment of uses and employment modalities (Hurrell and Pochettino 2014; Hurrell et al. 2011, 2013).

3. Manifestation of knowledge in actions is resonant with the concept of embodiment of knowledge (Martínez 2008; Varela 1990). When we say: 'knowledge guide the actions', we mean that knowledge is embodied in diverse behaviors that become adaptive (Hurrell and Albuquerque 2012).

4. Urban botanical knowledge is dynamic. It is a system co-constructed by the different actors of the urban scenario in their interactions over time, whereby the system guides actions with adaptive value. The changes in the circulation of plant products and employment strategies that are assigned reflect this dynamic nature (Hurrell and Pochettino 2014).

5. Transmission of urban botanical knowledge is not unidirectional (linear), as it is the transmission from generation to generation prevailing in the dissemination of traditional botanical knowledge. In the urban context, knowledge transmission 
occurs simultaneously in multiple directions (from parents to sons and vice versa, between individuals of the same generation and other, and other ways of disseminating). Knowledge transmission is complex, and can be very fast: mass media have a disperser/accelerator effect (Pochettino and Hurrell 2013).

\section{Study Area}

The research line in Urban Ethnobotany of the LEBA develops in the large metropolitan area Buenos Aires-La Plata. This is located in the Río de la Plata region: the areas of influence of the lower courses of the Parana and Uruguay rivers, and the upper and middle sectors of the Río de la Plata. It includes the lower Parana delta (in Entre Ríos and Buenos Aires provinces), and the riversides of Argentina (Buenos Aires) and Uruguay. Its approximate area is $60,000 \mathrm{~km} 2$ (Figure 2).

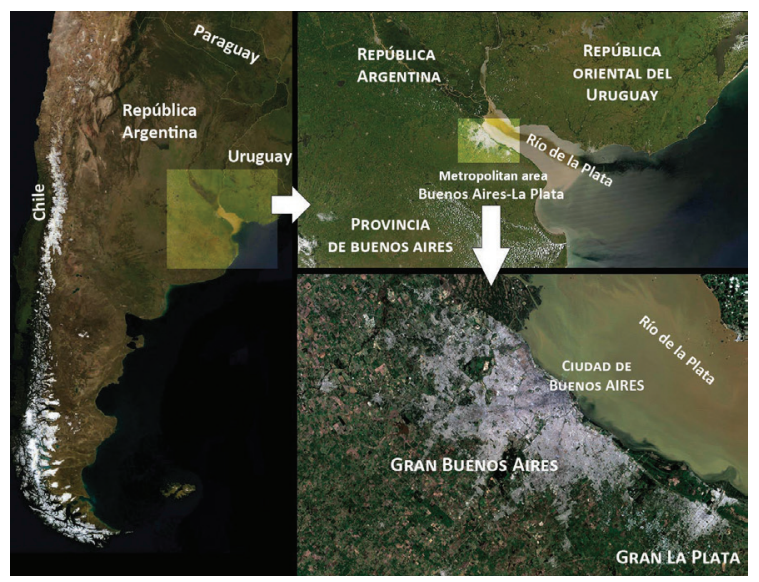

Figure 2. Study area location (Satellite images from NASA).

The conurbation Buenos Aires-La Plata includes two contiguous urban agglomerations: 'Gran Buenos Aires', around Buenos Aires city (the country capital), and 'Gran La Plata', around La Plata city (capital of the Province of Buenos Aires). In total, have about $5000 \mathrm{~km} 2$ and $13,800,000$ inhabitants in 2010. 'Gran Buenos Aires' has some $13,000,000$ inhabitants in $3850 \mathrm{~km} 2$. Within this, the country capital has $3,000,000$ inhabitants in only 203 km2. 'Gran La Plata' has about 800,000 inhabitants in $1150 \mathrm{~km} 2$. According to these numbers, the metropolitan area of Buenos Aires is the largest in Argentina, South America's second, third Latin American and the seventeenth in the world.

The following sectors are included within the metropolitan area:

- Sectors with spontaneous vegetation, generally residual (including protected areas of different levels: national, provincial, municipal, and private).

- Sectors with agricultural activities (some rural few areas).

- Sectors exclusively urban (the largest areal extension).

- Sectors called 'periurban'. These are transitional zones between the purely urban space and the rural, and/or spontaneous vegetation areas, with development of horticultural activities both in homegardens as in productive orchards. These periurban areas have been considered within the urban scenario in a functional sense: they are most closely related with the purely urban areas, and its extension depends on the rhythm of urbanization (Barsky 2010; Hurrell et al. 2011). Also, due to the horticultural activity, the periurban sector is a source of plants and products for consumption in urban areas themselves. Therefore, the 'periurban' is integrated to the urban communication web.

\section{Research line}

In studies of the research line of LEBA were excluded rural areas because its peculiar features, clearly distinct from those of urban areas. In the remaining three sectors the following studies are developed:

- Sectors with spontaneous vegetation: Floristic and ethnobotanical surveys (native plants used for various purposes, particularly in popular medicine, biological invasions and environmental change).

- 'Periurban': Floristic and ethnobotanical surveys in different homegardens (local horticultural activities, weeds, 
naturalization and invasion of exotic species, environmental changes).

- Sectors exclusively urban: Ethnobotanical studies in outlets of the general commercial circuit, as the called dietéticas (health-food stores) that sell 'healthy' products, especially, dietary supplements. Ethnobotanical surveys were conducted simultaneously in outlets belonging to different immigrants segments. To date we have worked with two sets of immigrants: 1) Bolivian immigrants who sell its plant products in a traditional market (street stalls and premises) located in the Liniers neighborhood of Buenos Aires city, 2) Chinese immigrants who sell its plant products in shops located in the so called Barrio Chino ('Chinatown') at neighborhood of Belgrano, in the same city (Hurrell et al. 2011; Hurrell and Pochettino 2014; Pochettino et al. 2012b).

The ethnobotanical survey data followed the usual qualitative methodological guidelines: interviews (both open and semi-structured), participant observation, free listings (Albuquerque et al. 2010; Etkin and Ticktin 2010, Quinlan 2005; Stepp 2005). The sellers both sexes and different ages, that demonstrate they knowledge about uses and properties of the products they sell were considered 'qualified informants'. The procedures always were performed with the consent of the informants. In all cases, reference samples of plants, its parts thereof, and products derived were collected and deposited in the LEBA. The available literature on species uses and the information on labels, leaflets and advertisements, in print and electronic media were reviewed. This information as well as the obtained from the informants constitutes that we call the 'assigned uses'. Bibliographic data on the biological activity and effects studied, in order to compare uses assigned and properties with scientific support were also reviewed (Arenas et al. 2011, Hurrell et al. 2013).

\section{Methodological strategies and contributions}

The methodological strategies and contributions that until now emerge from our research line in Urban Ethnobotany are expressed in the following criteria:

1. Exclusivity of plant products (referring to urban botanical knowledge composition)

If a plant product (plants, its parts thereof, products derived) is situated in the general commercial circuit it is recorded as generalized, and it is assumed linked to non-traditional botanical knowledge. In contrast, if a plant product is located in the immigrants segment context, it is recorded is as exclusive and it is assumed related to botanical knowledge linked to their cultural traditions (Figure 3).

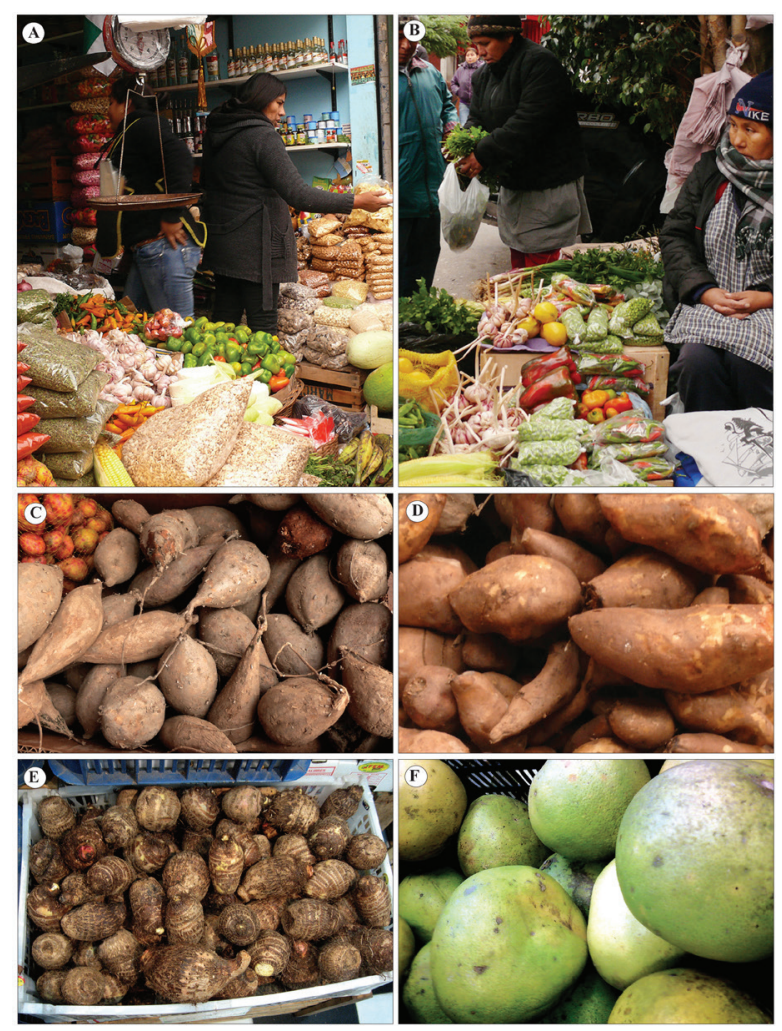

Figure 3. Bolivian traditional market at Liniers, Buenos Aires city: A. Premises. B Street stalls. C. 'Ahipa roots'. D. 'Yacon roots'. Chinese supermarket at 'Barrio Chino', Belgrano, Buenos Aires city: E. 'Taro rhizomes'. F. 'Chinese pomelo fruit'. 
For instance: 'ahipa roots', Pachyrhizus ahipa (Wedd.) Parodi (Leguminosae), and 'caigua fruits', Cyclanthera pedata (L.) Schrader (Cucurbitaceae) are exclusive products of the traditional Bolivian market of Buenos Aires city; 'taro rhizomes', Colocasia esculenta (L.) Schott (Araceae) and 'Chinese pomelo fruit', Citrus maxima (Burm.) Merr. (Rutaceae), are exclusive products of the Chinese premises of Barrio Chino, in the same city.

Distinct products of the same species can be found in different situations. 'Yacon', Smallanthus sonchifolius (Poepp. \& Endl.) H. Rob. (Asteraceae) is an example: its 'fresh roots' is an exclusive product of the Bolivian immigrants segment, but the 'yacon extract' (dietary supplement) is found in the general commercial circuit, therefore it is a generalized product.

\section{Visibility of plant products (referring to urban} botanical knowledge dynamics)

Exclusive plant products (linked to traditions) are invisible to majority of the urban population (non-immigrant). On the other hand, generalized products installed in the general commercial circuit are visible to all inhabitants (including immigrants). Should be noted that 'exclusive' and 'generalized' products are categories related to the urban botanical knowledge composition, that is, the embodiment of the latter expressed in the presence of products in different contexts. 'Exclusive' and 'invisible' are not synonymous, as well as 'generalized' and 'visible' are not. 'Invisible' and 'visible' categories are related to processes linked with products circulation dynamics.

Invisible plant products may become visible when they enter into the general commercial circuit. This passage from the restricted circuit of immigrants to the wider general commercial circuit is considered a visualization process (Figure 4). This process may be faster or slower depending to the multiplier effect of different visualization agents like the mass media, mainly Internet. The dietéticas constitute other relevant visualization agents. In the studies conducted were detected some 'invisible' plant products with very fast dissemination, and that entered the general commercial circuit through the dietéticas. Just two examples: 'sacha inchi', Plukenetia volubilis L. (Euphorbiaceae), from the Bolivian immigrants segment, and 'goji', Lycium barbarum L. (Solanaceae), from the Chinese segment, both became visible in less than 5 years ago (Hurrell et al. 2013).

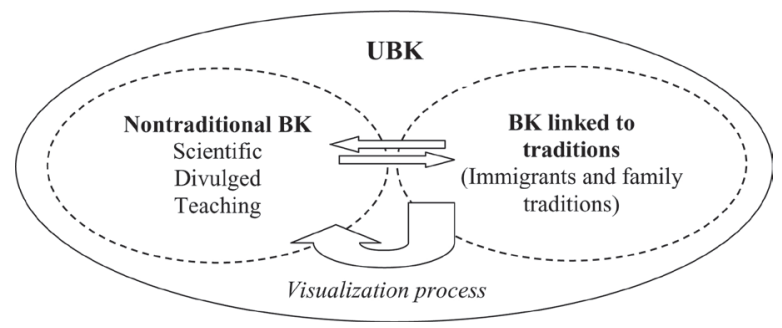

Figure 4. Urban botanical knowledge composition: non-traditional botanical knowledge interacting with botanical knowledge linked to traditions. The passage from the second component to the first constitutes the visualization process.

3. Re-signification of uses (referring to urban botanical knowledge transmission)

The dietéticas and the mass media enhance the transmission of the urban botanical knowledge, but not without modifications. In the context change from the circuit linked to traditions to the nontraditional one, the uses originally assigned to plant products are re-signified. Sometimes a displacement of meaning occurs from a traditional use to other related (most suitable for the urban context). Other times, there are assignments of new uses, not necessarily related with the traditional ones.

'Maca', Lepidium meyenii Walp. (Brassicaceae) is an example of displacement of meaning. It is native to the Andean region where it is used to enhance animal and human fertility (biological activity assessed), among other uses. In the urban context is marketed (as dietary supplement) like an aphrodisiac (is promoted as 'vegetal viagra'). The assessment of its aphrodisiac effect is not conclusive and still generates controversy (Arenas et al. 2011).

'Açai', Euterpe oleracea Mart. (Arecaceae), is a case of assignments of new uses. In the Amazon it is employed as energizing and to fight infections, among other utilities. Its antioxidant and immunostimulant activity have been evaluated (Hurrell et al. 2013). In urban scenario, its dietary supplement is sold as an aphrodisiac 
(is publicized as 'Amazon viagra'), but this use has no direct correlation with traditional uses linked to reproductive functions.

In general, the re-signification of uses is related to categories more in line with the demands of urban life: antioxidants, adaptogens, aphrodisiacs, slimming. Largely, the re-signification of uses depends on the strategies of products selling. These are often based on mixed criteria, like: a) Traditionality ('the product is good because it has an ancestral use'), b) Scientificity ('it is good because is scientifically proven'). Products with this double assigned value ('ancestral + scientifically proven') are widespread, because the strategy tends to increase the universe of receptors and also captivates the more eclectic urban public.

\section{FINAL REMARKS}

\section{Recursivity of knowledge and action}

The botanical knowledge transmission in pluricultural contexts is a complex phenomenon, then, the basic premise that knowledge guides the actions needs to be rethought. This premise has descriptive value for some situations, and in that sense has been used before in this paper. However, it is insufficient from an integrative explanatory viewpoint (Pochettino and Hurrell 2013). Considering the re-signification of uses that occur in the passage from traditional context to non-traditional (a context change always involves a meaning change), a new kind of knowledge emerges by displacement of meaning and/or assignments of new uses. In this framework, knowledge guides actions that feedback into knowledge (Figure 5).

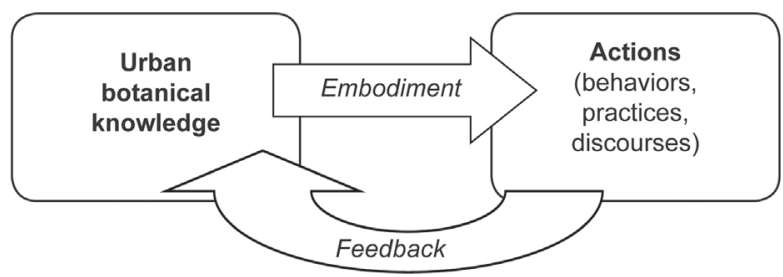

Figure 5. Urban botanical knowledge embodied in actions, and feedback from actions on urban botanical knowledge.
In conclusion, the process is not just linear (from knowledge to action) but recursive (from knowledge to action, from action to knowledge, and so on), which increases the complexity of our explanatory models in correlation with the complexity of the phenomena that we wish to explain ${ }^{6}$.

\section{Local botanical knowledge}

The complexity of botanical knowledge in the urban pluricultural contexts (with nontraditional components and other linked to different traditions) has been cause for reflection. Perhaps, be important to ask ourselves about the relevance of also reflect on the botanical knowledge complexity in culturally homogeneous contexts. In these contexts, we can say that the traditional botanical knowledge prevails over the non-traditional, because usually it is difficult to deal with a traditional botanical knowledge 'in a pure state'. Consequently, it is necessary to reflect about how interact both kinds of botanical knowledge (traditional and non-traditional) in culturally homogeneous contexts, and how is the impact of these interactions within the 'manenvironment' system, considering its biocultural complexity. For the purposes of future debates, it could be more appropriate to talk about local botanical knowledge instead of 'traditional' and 'non-traditional'. In a complex way, we could consider a knowledge system with non-traditional components and other linked to traditions that prevail over one another according to each cultural context (homogeneous at one end, heterogeneous at the other).

In conclusion, the theoretical and methodological contributions characteristic for urban pluricultural contexts might apply to culturally homogeneous contexts. Thus, the explanatory models of Urban Ethnobotany can bring valuable tools to the explanatory models of Ethnobotany in general.

6 Recursivity is at the basis of reflection (re-think the thoughts), so it is not something stranger to ourselves. 


\section{Complexity on botanical knowledge}

According to the foregoing, the local botanical knowledge (both urban and not urban) is a complex system co-constructed by the different actors in their (recursive) interactions over time. This knowledge is accessible to us only through the actions (discourses) of the actors involved. Furthermore as stated before, the discourse of the informants interviewed allows us to reformulate their underlying knowledge. In the reformulation process, the called ethnoscience is involved as a methodological approach, not as a disciplinary field (for a wider discussion, see Alves and Albuquerque 2010). From a methodological viewpoint, ethnoscience constitutes an analytical 'metalevel' because our study object is not the botanical knowledge in a direct way, but the discourse of the informants about their own knowledge and actions (behaviors) that orient. In this context our explanations (as researchers) emerge from the (recursive) dialogue with informants, i.e. 'the others' (Albuquerque and Hurrell 2010; Alves and Albuquerque 2010). Knowledge is co-constructed because emerge from our relationships with 'the others' (relationships that are expressed in recursive interactions). In this epistemological context, the researcher is not divorced of his study object, at the same time that is responsible for the results of their own research. As well as the organism (man included) is not separated from its environment, the researcher is not dissociated from his research.

In conclusion, the botanical knowledge (as all knowledge) is the result of a co-construction between all actors involved, i.e. not only the researched subjects ('the others') but also the researcher. Assumed the complexity of botanical knowledge only remains the challenge of generating consistent explanatory models.

Finally, as Edgar Morin tell us: 'complexity is a challenge and not an answer' (Morin 1990).

\section{ACKNOWLEDGEMENTS}

The author especially thank to Ulysses P. de Albuquerque, Recife (Brazil), María Lelia Pochettino and the integrants of LEBA, La Plata (Argentina) for their constant support, and to Alejandro Pizzoni for his critical reading of the manuscript.

\section{REFERENCES}

1. Albuquerque UP, Hurrell JA (2010) Ethnobotany: one concept and many interpretations. In: Albuquerque UP, Hanazaki N (Eds), Recent developments and case studies in Ethnobotany. SBEE/ NUPEEA, Recife, pp. 87-99.

2. Albuquerque UP, Favias Piava LR, Fernandez LV (Eds.) (2010) Métodos e técnicas na pesquisa etnobiológica e etnoecológica. NUPPEA, Recife.

3. Alves AGC, Albuquerque UP (2010) "Ethno what?" Terminological problems in ethnoscience with a special emphasis on the Brazilian context. In: Albuquerque UP, Hanazaki N (Eds), Recent developments and case studies in Ethnobotany. SBEE/NUPEEA, Recife, pp. 67-79.

4. Arenas PM, Cristina I, Puentes JP, Buet Costantino F, Hurrell JA, Pochettino, ML (2011) Adaptógenos: plantas medicinales tradicionales comercializadas como suplementos dietéticos en la conurbación Buenos Aires-La Plata (Argentina). Bonplandia (Corrientes) 20(2):251-264.

5. Barsky A (2010) La agricultura de "cercanías" a la ciudad y los ciclos del territorio periurbano. Reflexiones sobre el caso de la Región Metropolitana de Buenos Aires. In: Svetlitza A (Ed.) Agricultura periurbana en Argentina y globalización. Escenarios, recorridos y problemas. FLACSO, Buenos Aires, pp. 15-29.

6. Bateson G (1972) Steps to an ecology of mind. 1 ed. Ballantine Books, New York.

7. Bateson G (1979) Mind and Nature. A Necessary Unity. 1 ed. Dutton, New York.

8. Cuassolo F, Ladio AH, Ezcurra C (2010) Aspectos de la comercialización y control de calidad de las plantas medicinales más vendidas en una comunidad urbana del NO de la Patagonia Argentina. Bol Latinoam Caribe Plant Med Aromat 9(3):166-176.

9. Etkin NL, Ticktin $T$ (2010) Advancing an ethno-ecological perspective that integrates theory and method in ethnobotany. In: Albuquerque UP, Hanazaki N (Eds), Recent developments and case studies in Ethnobotany. SBEE/NUPEEA, Recife, pp. 33-57.

10. Flos J (1984). Ecología entre la magia y el tópico. 1 ed. Omega, Barcelona.

11. Flos J (2005) El concepto de información en la ecología margalefiana. Ecosistemas 14 (1): 7-17.

12. Guerra Sierra A, del Hierro SP (2008) La descomposición de la ecología. Netbiblo, Oleiros.

13. Hilgert NI, Higuera ML, Kristensen MJ (2010) La medicina herbolaria en el contexto urbano. Estudio de caso en un barrio de la ciudad de Tandil, Argentina. Bol Latinoam Caribe Plant Med Aromat 9(3):177-190.

14. Hurrell JA (1987) Las posibilidades de la etnobotánica y un nuevo enfoque a partir de la ecología y su propuesta cibernética. Revista Española de Antropología Americana (Madrid) 17:235257.

15. Hurrell JA, Albuquerque UP (2012) Is Ethnobotany an Ecological Science? Steps towards a complex Ethnobotany. Ethnobiology and Conservation 2012, 1: 4. Disponible: <http:// ethnobioconservation.com> [Consulta: 8-IX-2013]. 
16. Hurrell JA, Delucchi G (2013) Aportes de la Etnobotánica al estudio de las invasiones biológicas. Casos en la región rioplatense (Argentina). Historia Natural (3ra. Serie) 3 (2) (in press).

17. Hurrell JA, Pochettino ML (2014) Urban Ethnobotany: theoretical and methodological contributions. In: Albuquerque UP, Cruz da Cunha LVF, Lucena RFP, Alves RRN (Eds.), Methods and techniques in Ethnobiology and Ethnoecology. Springer, Berlin, pp. 293-309.

18. Hurrell JA, Ulibarri EA, Puentes JP, Buet Costantino F, Arenas PM, Pochettino ML (2011) Leguminosas medicinales y alimenticias utilizadas en la conurbación Buenos Aires-La Plata, Argentina. Bol Latinoam Caribe Plant Med Aromat 10(5):443-455.

19. Hurrell JA, Pochettino ML, Puentes JP, Arenas PM (2013) Del marco tradicional al escenario urbano: Plantas ancestrales devenidas suplementos dietéticos en la conurbación Buenos Aires-La Plata, Argentina. Bol Latinoam Caribe Plant Med Aromat 12(5):499-515.

20. Kroeber A. 1920. Review of "Uses of plants by the indians of the Missouri River Region" by Melvin R. Gilmore. Amer Anthropol 22:384-385.

21. Ladio AH, Molares S, Ochoa J, Cardoso B (2013) Etnobotánica aplicada en Patagonia: la comercialización de malezas de uso comestible y medicinal en una feria urbana de San Carlos de Bariloche (Río Negro, Argentina). Bol Latinoam Caribe Plant Med Aromat 12(1):24-37.

22. Maffi L (2001) Introduction. On the interdependence of biological and cultural diversity. In: Maffi L (Ed.), On biocultural diversity. Linking language, knowledge, and the environment. Smithsonian, Washington, pp. 1-50.

23. Maffi L (2005) Linguistic, Cultural, and Biological Diversity. Annual Review of Anthropology 29: 599-617.

24. Maffi $L(2007)$ Biocultural diversity and sustainability. In: Pretty J, Ball AS, Benton T, Guivant J, Lee DR, Orr D, Pfeffer MJ, Ward $H$ (Eds.), The SAGE Handbook of Environment and Society. SAGE Publ., London, pp. 267-277.

25. Margalef $R$ (1980) La biosfera: entre la termodinámica y el juego. 1 ed. Omega, Barcelona.

26. Margalef R (1986) Ecología. 1 ed. Omega, Barcelona.

27. Margalef $R$ (1990) Historia natural del cambio en sistemas organizados. In: Wagensberg $\mathrm{J}$ (Ed.) Sobre la imaginación científica. Tusquets, Barcelona, pp. 141-169.

28. Margalef R (1991) Teoría de los sistemas ecológicos. 1 ed. Universitat de Barcelona, Barcelona.

29. Martínez SF (2008) La cognición corporizada en prácticas: implicaciones para la filosofía de la ciencia. In: Martínez SF Huang $X$, Guillaumin G. (eds) Historia, prácticas y estilos en la filosofía de la ciencia: hacia una epistemología plural. UNAM, México, pp. 212-231.

30. Maturana H, Varela F (1972) De máquinas y seres vivos. 1 ed. Editorial Universitaria, Santiago de Chile.

31. Morin E (1973) Le paradigme perdu: la nature humaine. 1 ed. Seuil, Paris.

32. Morin E (1980) Le Méthode II. La vie de la Vie. 1 ed. Seuil, Paris.

33. Morin E (1982) Science avec conscience. 1 ed. Fayad, Paris.

34. Morin E (1985) O Problema Epistemológico da Complexidade. 1 ed. Publ. Europa-America, Lisboa.

35. Morin E (1990) Introduction à la pensée complexe. 1 ed. ESF Editeur, Paris.
36. Pirondo A, Coulleri JP, Keller HA, Ferrucci MS (2011) Influencia de factores externos sobre la comercialización de plantas medicinales en un medio urbano: el caso de vendedores criollos e indígenas en Corrientes, Argentina. Bol Latinoam Caribe Plant Med Aromat 10(6):553-569.

37. Pochettino ML, Hurrell JA (2013) Saberes y plantas en las diagonales: transmisión del conocimiento botánico urbano. Bol. Soc. Argent. Bot. 48 (Supl.): 16.

38. Pochettino ML, Lema $V$ (2008) La variable tiempo en la caracterización del conocimiento botánico tradicional. Darwiniana 46:227-239.

39. Pochettino ML, Hurrell JA, Lema VS (2012a) Local botanical knowledge and agrobiodiversity: homegardens at rural and periurban contexts in Argentina. In: Luna Maldonado Al (Ed.), Horticulture. InTech, Rijeka, pp. 105-132.

40. Pochettino ML, Puentes JP, Buet-Costantino F, Arenas PM, Ulibarri EA, Hurrell JA (2012b) Functional Foods and Nutraceuticals in a Market of Bolivian Inmigrants in Buenos Aires (Argentina). Evidence-Based Complementary and Alternative Medicine 2012, doi:10.1155/2012/320193

41. Prigogine I (1972) La thermodynamique de la vie. La Recherche $3(24): 547-562$

42. Quinlan $M(2005)$ Considerations for collecting freelists in the field: examples from Ethnobotany. Field Methods 17(3):1-16.

43. Rapoport EH, Marzocca A, Drausal BS (2009) Malezas comestibles del Cono Sur y otras partes del planeta. INTA, Buenos Aires.

44. Richeri M, Beeskow AM, Ladio AH (2010) Las plantas y la salud en la comunidad boliviana de Puerto Madryn (Argentina). In: Pochettino ML, Ladio AH, Arenas PM (Eds.) Tradiciones y Transformaciones en Etnobotánica. CYTED-RISAPRET, San Salvador de Jujuy, pp. 297-302.

45. Rovere AE, Molares S, Ladio AH (2013) Plantas utilizadas en cercos vivos de ciudades patagónicas: aportes de la etnobotánica para la conservación. Ecología Austral 23:165-173.

46. Stepp JR (2005) Advances in ethnobiological field methods. Field Methods 17(3):211-218.

47. Thienemann AF (1956) Leben und Umwelt. Von Gesamthaushalt der Natur. 1 ed. Rowohlt, Hamburg.

48. Varela F (1990) Conocer.1 ed. Gedisa, Barcelona.

Received: 01 February 2014

Accepted: 29 April 2014

Published: 12 June 2014 